\title{
IMPROVING QUALITY OF THE RAILWAY TRANSPORT THROUGH THE APPLICATION OF THE THEORY OF CONSTRAINTS
}

\author{
POBOLJŠAVANJE KVALITETE ŽELJEZNIČKOG PRIJEVOZA \\ PRIMJENOM TEORIJE OGRANIČENJA
}

\author{
Ing. Michal Petr Hranický \\ Doc. Ing. Eva Nedeliaková, PhD. \\ Ing. Adrián Kuka \\ University of Zilina \\ Univerzitná 8215/1, 01026 Žilina, Slovakia/Slovačka \\ E-mail: eva.nedeliakova@fpedas.uniza.sk
}

UDK/UDC: 005.6:656.2+686.1.01

JEL klasifikacija/JEL classification: L15; L92

DOI: $10.30657 / \mathrm{hdmk} .2020 .19$

Pregledni članak/Review

Jezik/Language: Engleski/English

\begin{abstract}
The paper is focused on the real application of the theory of constraints for the profession of locomotive driver. For this purpose, the theoretical side of the issue is also solved in terms of logistics with the subtitle "Position of the locomotive driver in the transport process". These roles are illustrated in diagrams. Finally, the bottlenecks and proposals for their elimination are analysed in more detail.
\end{abstract}

Key words: quality in railway transport, locomotive driver, theory of constraints.

\section{INTRODUCTION}

Quality in rail transport has recently been an increasingly mentioned topic. If we want to evaluate quality from the customer's point of view, it is needed to take into account all partial factors. For the services at the required quality level, it is necessary to reach the required level of quality of each process activity, in each process step of the transport process. In rail transport, one of the key subjects is the locomotive driver. Even if it does not come into direct contact with the passenger, the performance of his service may affect the final perceived quality. ${ }^{1,2}$

The locomotive driver is a key link in the transport chain in rail transport and is an integral part of it. In recent years, however, a number of problems have arisen around this profession. On the one hand, deteriorating working conditions, increasing stress, an increasing lack of qualified drivers, etc. For this reason, we see great reserves in the possibilities of innovating the

\footnotetext{
${ }^{1}$ Miroslav Drljača and Vesna Sesar, V., "Quality factors of transport process”, Transportation Research Procedia, Vol. 40, 2019, pp. 1030-1036.

${ }^{2}$ Renata Nováková, Jana Šujanová and Alena Pauliková, „Use of $8 \mathrm{~d}$ method in nonconformity resolution - A case study of production of spliced veeners in Slovakia“, Drvna Industrija, Vol. 68, Issue 3, 2017, pp. 249-260.
} 
system for organizing this job position. For successful implementation it is necessary to propose effective and efficient changes. For this reason, it is important to carry out a thorough analysis first, followed by analysing their results.

\section{POSITION OF THE LOCOMOTIVE DRIVER IN THE TRANSORT PROCESS}

To analyse the position of the driver in the transport process, it is appropriate to first theoretically define the term process and transport process. The process can be understood as the sum of mutually ordered activities transforming inputs into outputs while consuming certain resources under regulated conditions. The inputs supplied by internal or external suppliers are all consumed in the output process. Tangible outputs are the result (product) of a process that has its customer. Resources are not consumed during the process, but are a prerequisite for its implementation (eg people, technology, information systems, etc.).

When analysing the locomotive driver's position in the transport process, the question arises as to how irreplaceable his role is. Nowadays, with technical progress, we can increasingly encounter more or less autonomous means of transport. The term autonomous is an increasingly inflected word in logistics and is gaining in importance. The Academic Dictionary of Foreign Words defines the term autonomous as "self-government, a form of certain relative autonomy within a larger whole, independent decision-making while maintaining the unity of the whole". ${ }^{3}$

There are already concepts of autonomous warehouses controlled exclusively by machines. Similarly, there are various tests of autonomous vehicles for the transport of goods and passengers. In the Czech Republic, the issue is dealt with by the Platform for fully autonomous vehicles, which was initiated by the Ministry of Transport in 2017. This platform addresses the following five basic issues of autonomous vehicles:

- legal aspects,

- social and ethical issues,

- technology,

- transport and digital infrastructure, security and spatial data,

- verification and conformity assessment.

The scale defined in 2014 by the Automotive Industry Association SAE International can be used to assess the level of automation. It consists of a six-point scale and is applied to the railway transport environment as follows: ${ }^{4,5}$

- $\quad 0$ - no automation, the automatic system only warns the driver in the event of danger or other non-standard situations, but does not control the locomotive itself;

- 1 - driver assistance ("hands on"), more complex functions can be performed automatically, eg automatic speed control, automatic speed change after a certain distance calculated based on the number of train axles, the system only makes driving easier;

- 2 - partial automation ("hands off"), automatic control, acceleration and braking, but the driver must always monitor the operation, control system operation and be able to intervene and take control at any time (automatic train driving it only gives its consent for the train to move);

\footnotetext{
${ }^{3}$ Věry Petráčková, Akademický slovník cizích slov, Academia, Praha, 1997.

${ }^{4}$ Nicholas Negroponte, Being digital, Vintage Books, 2000.

${ }^{5}$ Dorothy J. Glancy, “A Look at the Legal Environment for Driverless Vehicles”, Washington, DC: Transportation Research Board, 2016.
} 
- 3 - conditional automation ("eyes off"), in a defined environment the driver does not have to devote himself to driving, but must be prepared to take control within the time limit set by the manufacturer;

- 4 - high automation ("mind off"), with the exception of dangerous or non-standard environment (dangerous weather conditions, track closures), the train is controlled by the machine and the driver does not intervene;

- 5 - full automation ("control optional"), the automatic system controls the train completely autonomously, the driver is not needed.

In the current conditions of Czech and Slovak railways, only automation levels $0-2$ are used. Fully autonomous trains in the world find their use only in city railways (underground) where there is no risk of collision with an obstacle on the line between stations. In most cases, it is also possible to assume remote control of a train from a remote control room in an emergency. On classic national railways, autonomous trains are only under development (eg Amtrak in the United States of America), with the exception of Australia, where the autonomous train has successfully passed a $100 \mathrm{~km}$ track during the tests. However, even in this case, the presence of a driver is still required in case of an emergency. It is clear from the above information that the driver's role is currently crucial and irreplaceable in rail transport and will continue to be at least in the coming decades. The lack of drivers is an acute problem and therefore it cannot be expected to be gradually eliminated in the near future due to technical progress.

When considering the driver's role in the transport process, the term process approach should be mentioned. Process approaches require the use of basic management functions that are characterized by sets of managerial activities in the work process. They take advantage of adapting to new trends, overcome rigid structures and are prepared for environmental changes. The division of company activities into individual processes is important not only in the phase of transition to process management, but also in the further progress of companies. Continuous analysis of individual processes reveals the hidden bottlenecks of the processes and the possibilities of their optimization so that they meet the required criteria. The criteria are based on customer requirements in order to improve the quality of railway transport from their point of view.

The classification of partial processes is characterized by its positives and negatives. A positive aspect is that process approaches are classified, structured principles and aspects are widely accepted in other approaches (especially system approaches). Processes and a good view of them are an important part of successful management. If we define the transport process as mentioned above, it can be said that the driver is involved in it all the time, for all tasks related to the locomotive. The driver is a co-factor and thus a part of the process also in other partial processes, for example change of the locomotive in the station which is neither the starting one nor the terminus. While it is true that certain tasks in the transport process may be performed by another employee, it is also usually the driver (eg preparation of the locomotive, shunting to a station where the employee only takes it). We consider the transport process as a chain of events from the customer's perspective. Figure 1 shows a diagram of the simplified passenger transport process by the passenger, indicating the employees involved.

The transport process theoretically begins with the creation of a transport request, then we assume that the passenger seeks a suitable train connection. In the diagram, cashier participation is only possible here, as the passenger can ask him to find a connection directly to the station upon arrival, but he can also find it himself via the Internet or a printed timetable. This is followed by the purchase of a travel document, which can also be made on the Internet via an e-shop or mobile application. 
Figure 1. Diagram of transport processes for passenger, courier and cargo

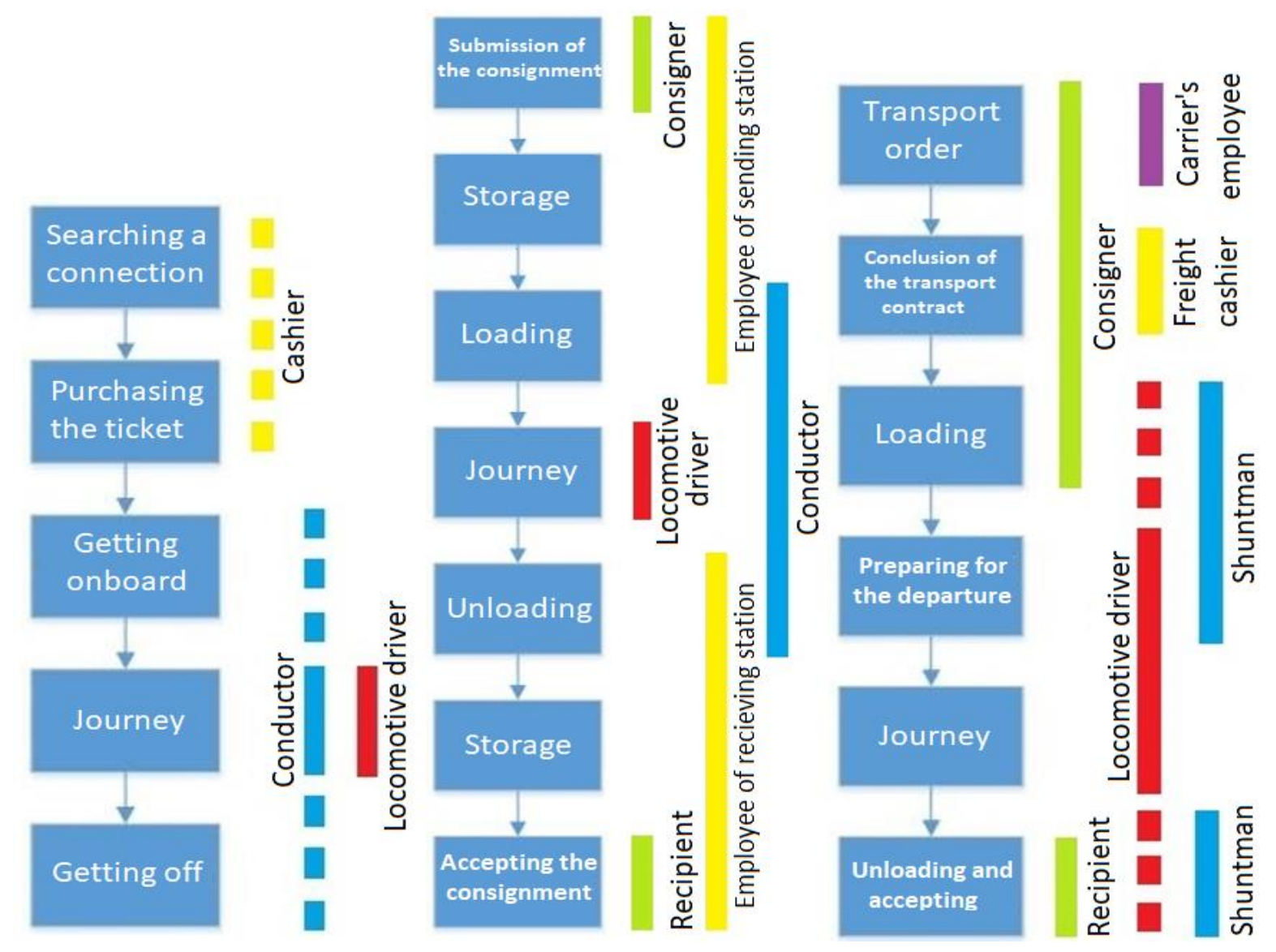

Source: Made by authors.

As can be seen from the diagram, the entire transport process can be carried out without the cashier's participation. This is one of the reasons why in some Western European countries the trend of limiting these workers prevails (in some stations, for example, there are only ticket machines). This represents a significant money saving. However, it can be a negative phenomenon in terms of service quality, as a trained worker can advise a passenger better than a vending machine and some passengers will also appreciate the human approach.

Passengers with a valid ticket will move to the platform where they will wait for the train to arrive. On boarding the presence of a train crew is possible (assistance with boarding, or information on where the train goes), but it is not necessary, the same applies to ascent. It can be seen from the diagram that, from the passenger's point of view, the driver is only involved in the carriage of the train during the movement itself. It is necessary to add to the diagram that it is only a simplified and model example, transport can be carried out in many other variants (eg sale of a train ticket on the way from stations without a cashier, requests for connections waiting, etc.).

The courier shipment was selected as the second example (see Figure 1). In this case, the customer does not participate in the transport itself. The consigner submits the consignment for transport to the employee of the posting station (in some cases the consignment is taken over by the cashier), the employee stores the consignment in the warehouse until the arrival of the planned train, when the consignment is handed over to the train crew. The train crew is responsible for the consignment while the train is running. At the destination station, it will then hand it over to the station employee who will store it until the recipient arrives. In this case, 
therefore, the sender or receiver of the package only participates in the first and last steps, the remaining part of the transport chain being carried out solely with the participation of the carrier's employees. As highlighted in red, the driver in this case again takes part in the train movement only. Again, this is only a model example, in practice, for example, there are often reloads of consignments during transport.

Figure 1 also shows a diagram of the freight transport process. The first step is to order the shipment by the sender, which is approved by the authorized employee of the carrier. Once approved, the contract of carriage is physically concluded by signing the consignment note, which can be carried out by the consigner in cooperation with the cashier. The following is the loading of the goods, which must be sent to a predetermined place, where it is taken over and loaded in cooperation with an authorized employee of the carrier. The highlighting of the driver's role is intermittent in this case, as it may or may not be involved in loading. There are types of loading where the driver's cooperation is needed (eg filling the wagon from the conveyor belt if no other wagon movement equipment is used), especially in cases where a consignment is loaded on multiple wagons and shunting is required. On the other hand, some consignments can be loaded even when the wagons are stationary and the locomotive is attached only after loading, so the driver is not involved.

Preparatory work follows before the train departs, which means brake test, etc. Here, the driver's cooperation is required (except for operations performed only with wagons - eg provision of train end signals, etc.). The last step is the unloading of the consignment and its receipt by the recipient from the authorized employee. Here, the driver may or may not be involved, similar to loading.

\section{APPLIATION OF THE THEORY OF CONSTRAINTS}

Theory of Constraints (TOC) or chain theory is the theory of E. M. Goldrath and is based on the removal of constraints from business processes to maximize flow and minimize inventory and operating costs. The method was initially presented on production examples, especially on production facility capacities, but soon the concept fell into the hands of software designers and engineers, and infiltrated into the management business through software solutions. E. M. Goldratt presented the idea on the example of a chain. Constraint of the company is therefore the weakest link of the imaginary chain and it is the strength of the weakest link that determines the strength of the whole system. A restriction is anything that prevents the goal from being achieved. Each system, including an enterprise, has a limitation that prevents the system from achieving a higher level of performance. One of the basic elements of the TOC method is the principle of causality, which means causality, a causal relationship between cause and effect. ${ }^{6}{ }^{7}$

Another is the principle of the Socratic method of questioning (currently 5 times why), the principle of five steps TOC:

- identification of restrictions,

- find out what influences the restriction and how it can be managed,

- adjusting the surrounding area to get the best performance,

- adjust the constraints to increase system performance,

- identification of a new restriction (return to first point). ${ }^{8}$

\footnotetext{
${ }^{6}$ Stanislaw Borkowski, Renata Stasiak Betlejewska and Adam Torok, "Theoretical investigation of supply chain service level in Hungary and Poland", Transport and Telecommunication, Vol. 14, Issue 2, June 2013, p. 93-101.

${ }^{7}$ Štefan Kudláč, Jozef Majercak and Peter Majercak, "Comparison of different variants of logistics chain with the use of air transport using the software application", Transportation Research Procedia, Vol. 28, 2017, pp. 45-50.

${ }^{8}$ Veronika Lencová., Kreativni management, Praha, 2016.
} 
The application of these steps was elaborated by Eliyahu M. Goldratt for production management and project management. Procedures according to the theory of constraints are used by sociologists to study and manage interpersonal relationships, people engaged in natural events, and many other disciplines. Everyone can use the theory of constraints for their individual development. ${ }^{9}$

When applying the theory of constraints in the case of driver performance, it is necessary to think of the entire transport process as a chain of events, looking for cases in which the driver or his activities are the weakest link, thereby limiting the whole process. These cases can be divided into those that can be removed and which cannot. Fixed process limitations that cannot be eliminated can be, for example: maximální délka směny strojvedoucího:

- the maximum length of the driver's shift,

- maximum driving time,

- maximum weekly performance,

- necessary technological times (locomotive preparation, moving from one control post to another during the shift, walking speed between depot and station, etc.),

- holiday,

- incapacity for work.

Some of the above restrictions on maximum working hours are based on the basis of the profession and are defined by the applicable legislation or internal regulations of the carrier. These maximum times serve to guarantee safety and prevent situations where the driver would be so exhausted by the work that there is a risk of their failure. In defined cases, especially in railway operations, they can be extended exceptionally, but usually only for a short period of time. Another category is technological time, which is based mostly on standardized data and represents the average duration of individual operations. They take into account the human factor and guarantee that the driver will carry out the tasks conscientiously and that he will not be under excessive pressure. Undersizing these times could lead to stress and unexpectable behaviour in important situations. ${ }^{10}$

Leave and incapacity are a limiting factor for carriers and occur in all jobs. Both categories are negative in terms of services and revenue generation, but they must be taken into account. The holiday is fixed and therefore it is easy to take it into account when creating tours and organizing drivers' work. On the other hand, incapacity for work cannot be predicted in advance and is therefore only foreseen by estimates. The case of excessive morbidity for drivers can bring about the need for operational changes and can have a detrimental effect on rail transport operations. Another group of limiting factors are those that can be eliminated in a certain way and thus increase the performance of the whole system in the sense of the limitation theory. These may include:

- Sick leave and other day offs are a limiting factor for carriers and occur in all jobs. Both categories are negative in terms of services, but they must be considered. The holiday is fixed and therefore it is easy to take it into account when creating shifts and organizing drivers' work. On the other hand, incapability for work cannot be predicted in advance and is therefore only foreseen by estimates. The case of excessive morbidity for drivers can bring about the need for operational changes and can have a detrimental effect on rail transport operations. Another group of limiting factors are those that can be eliminated in a certain way and thus increase the performance of the whole system in the sense of the limitation theory. These may include:

\footnotetext{
${ }^{9}$ Eliyahu Goldratt, Cíl: proces trvalého zlepšování, Hradec Králové: Interquality, 2001.

${ }^{10}$ Milan Dedík, Tomáš Čechovič, Jozef Gašparík and Jozef Majerčák, „,Rationalization of the passenger transport system as an important transport systém“, Transportation Research Procedia, Vol. 40, 2019, pp. 193-200.
} 
$>$ impossibility to put all the drivers for all the shifts (eg the driver has not the certification to lead such the concrete type of locomotive, faulty tests from foreign railway regulations, etc.),

$>$ obsolete type of locomotive,

$>$ total number of drivers employed,

$>$ downtime in locomotive drivers' shifts.

The inability to deploy drivers on all the trains is based on the fact that for each type of the locomotive the driver must be authorized. Theoretically, this limitation can be removed by extending the number of permissions. However, these authorizations entail the obligation of the driver not only to be familiar with the management of a given locomotive, but also in all systems (power transmission, hydraulics, air technology, electrical wiring, etc.). As their number increases, there is a risk that the driver will not remember all the necessary information. Creating the position of an "absolutely compatible driver" is not really possible.

Some train drivers' shifts includes trains running into the territory of another railway manager, either to the border station or further inland. This applies eg to the Žilina - Prague route. While driving through the Čadca border crossing station, the Czech driver goes to Žilina. When driving through the border station Horni Lidec Slovak driver goes to Olomouc or to Prague. For example, trains only go to the border station for trains from Košice to Budapest (Hídasnémeti station). All of these cases imply for the driver the need to have a knowledge test of the foreign railway authorities' traffic regulations and also the ability to communicate in the language of a foreign country at least to a limited extent in order to be able to communicate with the foreign infrastructure manager's dispatcher. These attributes represent additional limitations and the reason why some drivers cannot be allocated shifts with these trains.

Another factor is so-called track knowledge. To be able to safely guide a train on a track, the locomotive driver must know its conditions, so before the performance they must travel with another driver who knows the track and informs him about these situations. The internal regulations define the period during which this knowledge is valid and if the driver is not actively driving a train on this route during this period, the knowledge is forfeited and the train driving on this route cannot be assigned to him. The only exception is when another driver (the "pilot") is driving on the post to inform him about these facts. However, this is usually used only for extraordinary trips such as foreign locomotives etc. A limiting factor may be the very old locomotive itself, where the handling of key elements takes a disproportionately long compared to newer types. This weak link or bottleneck can be removed by investing in new locomotive, or by modernizing them, or partially by automating them. The number of drivers has proved to be particularly critical in recent years, when rail carriers are suffering from their shortage. Theoretically, this restrictive link can be removed by hiring new employees. However, experience confirms that this is a demanding task because, despite various motivational campaigns and other efforts, drivers are still lacking. The option is to "hire" employees from other carriers on the basis of an agreement (practiced especially in freight transport) or their recruitment abroad. Theoretically, it is possible to motivate employees of competing carriers to transfer to another company. ${ }^{11}$

The last example of a bottleneck is downtimes in train drivers' shifts (breaks when they don't drive). Downtimes are perceived negatively by both the carrier and the drivers themselves, so we can consider them as a negative phenomenon within the train driver's shift plan which has to be eliminated (it should be noted that some employees may appreciate rest beyond the mandatory breaks during downtime). Service downtime can be defined as a period of time within a given shift, when the driver does not actively operate the locomotive, does not travel by train, does not take the necessary (compulsory) break or rest time, or perform other

\footnotetext{
${ }^{11}$ Miloš Hitka, L'udmila Kozubíková and Marek Potkány, "Education and gender-based differences in employee motivation", Journal of Business Economics and Management, Vol. 19, Issue 1, 2018, pp. 80-95.
} 
technological tasks. The downtime usually occurs between the arrival of one train in a shift and the departure of a later one if the driver cannot be placed on the train earlier (or there is no earlier train). A similar case can occur not only after the train arrives, but after the end of the necessary rest (breaks or interruptions). This may result in unnecessarily long breaks in the shift. In the event of a prolonged interruption, the employee often does not draw any wages.

According to the possibility of elimination we can divide downtime into eliminable a non-eliminable. Unavoidable downtimes are those where it is not possible to adjust the shift plan so that the downtime is reduced or eliminated under given default parameters. Eliminable downtime arises when it is possible to adjust the tour so that the downtime is canceled or shortened. Sometimes, however, it is at the cost of other downtime. In order to find optimal shift plan without eliminable downtimes, it is necessary to solve this issue systematically. Systematic management of any business activity is currently associated with the active use of modern information technology with a well-established information system. Creating a suitable information system requires, inter alia, quantification of problems that is unthinkable without the use of mathematical and statistical models and methods. As a result of activities in the area of system approaches and especially quantitative approaches in the area of development and application of methods designed to support managerial decisions, a new scientific discipline occurred, which is still known as operations research, resp. operative analysis. ${ }^{12,13}$

Using the principles of operational analysis enabled the formalization of problems and the creation of an effective information system that provides the basis for their solution. An important prerequisite for objectification of decisions and their argumentation is to make a quantitative analysis of the status of operational processes. In order to eliminate downtime in drivers' shifts, it is possible to use eg the assignment task.

\section{CONCLUSION}

The paper analysed the profession of drivers and their position in the transport process. These two terms are theoretically defined in the introduction. Subsequently, the analysis of the driver's role in both processes is processed. Three model examples are chosen for the transport process (passenger transport, courier and freight), where the roles of the driver and other persons involved in these processes are shown in diagrams. Subsequently, we apply the theory of constraints to the driver's role, which is also defined first in theory. Examples are given where the driver may be the weakest link in the process. Some of these critical points can be eliminated, others not. In general, after analysis, the driver as a weak link under the theory of constraints is particularly critical in rail passenger transport, where high accuracy is required, as opposed to freight. A particularly important negative aspect is downtime in the train drivers' shift plan. After a theoretical analysis, it can be said that this issue is complex and needs to be addressed in greater depth. The driver profession has recently been in crisis not only because of the lack of skilled workers, but also because of the drivers' motivation and the conditions of their work. Therefore, proposing effective changes is not an option but a necessity.

\footnotetext{
12 Peter Virdzek and Katarína Teplická, „Progressive methods in design and their application in engineering industry“, Metalurgija, Vol. 45, Issue 4, October 2006, pp. 347-351.

${ }^{13}$ Radovan Madleňák and Lucia Madleňáková, „Digital advertising system in urban transport system of Žilina town“, Transport and Telecommunication, Vol. 15, Issue 3, 1 September 2014, pp. 215-226.
} 


\section{Sažetak:}

\section{POBOLJŠAVANJE KVALITETE ŽELJEZNIČKOG PRIJEVOZA PRIMJENOM TEORIJE OGRANIČENJA}

Rad je usmjeren na stvarnu primjenu teorije ograničenja u profesiji vozača lokomotiva (strojovođe). $U$ tu svrhu se teorijska strana problema rješava i u pogledu logistike s podnaslovom „Položaj strojovođe u procesu transporta". Ta je uloga prikazana dijagramima. Konačno, detaljnije se analiziraju uska grla i prijedlozi za njihovo uklanjanje.

Ključne riječi: kvaliteta željezničkog prijevoza, strojovođa, teorija organičenja.

\section{LITERATURE}

1. Drljača, M. and Vesna Sesar, „Quality factors of transport process“, Transportation Research Procedia, Volume 40, 2019. ISSN: 2352-1457.

2. Nováková, Renata, Šujanová Jana and Alena Pauliková, „Use of $8 \mathrm{~d}$ method in nonconformity resolution - A case study of production of spliced veeners in Slovakia“, Drvna Industrija, Volume 68, Issue 3, October 2017. ISSN: 0012-6772.

3. Petráčková, Věry, Akademický slovník cizích slov, Praha: Academia, 1997, ISBN: 80-2000607-9

4. Negroponte, N., Being digital, Vintage Books, 2000, ISBN: 978-0679762904.

5. Glancy, Dorothy, A Look at the Legal Environment for Driverless Vehicles, Washington, DC: Transportation Research Board, 2016, ISBN: 978-0-309-37501-6.

6. Borkowski, S., Stasiak-Betlejewska Renata and A. Torok „Theoretical investigation of supply chain service level in Hungary and Poland“, Transport and Telecommunication, Volume 14, Issue 2, June 2013, ISSN: 1407-6160.

7. Kudláč, Š., Majercak, J. and P. Majercak, „Comparison of different variants of logistics chain with the use of air transport using the software application", Transportation Research Procedia, Volume 28, 2017, ISSN: 2352-1457.

8. Lencová, Veronika, Kreativní management, Praha, 2016.

9. Goldratt, E., Cíl: proces trvalého zlepšování, Hradec Králové: Interquality, 2001, ISBN: 80-902770-1-2.

10. Dedík, M., Čechovič, T., Gašparík J. and J. Majerčák, „Rationalization of the passenger transport system as an important transport systém“, Transportation Research Procedia, Volume 40, 2019, ISSN: 2352-1457.

11. Hitka, M., Kozubíková L'udmila and M. Potkány, „Education and gender-based differences in employee motivation“, Journal of Business Economics and Management, Volume 19, Issue 1, 2018, ISSN: 1611-1699.

12. Virdzek, P. and Katarína Teplická, Progressive methods in design and their application in engineering industry, Metalurgija, Volume 45, Issue 4, October 2006, ISSN: 0543-5846.

13. Madleňák, R. and Lucia Madleňáková, „Digital advertising system in urban transport system of Žilina town“, Transport and Telecommunication, Volume 15, Issue 3, 1 September 2014, ISSN: 1407-6160. 